\title{
Aspartokinase of an Extreme Thermophile Thermus flavus Partial Purification and Some Properties
}

\author{
Takashi SaIKI, Ken Yamazumi* and Kei Arima \\ Department of Agricultural Chemistry, The University of Tokyo, \\ Bunkyo-ku, Tokyo \\ Received February 16, 1977
}

\begin{abstract}
Aspartokinase (ATP: L-aspartate 4-phosphotransferase) was extracted and partially purified 11-fold from an extreme thermophile, Thermus flavus AT-62. The enzyme has a temperature optimum near $75^{\circ} \mathrm{C}$ and a pH optimum of 7 to 8 . The enzyme activity was feedback inhibited $80 \%$ by L-threonine at the concentration of $0.1 \mathrm{~mm}$ at $60^{\circ} \mathrm{C}$. No concerted effect of $\mathrm{L}$-threonine with any other aspartate family amino acids was observed. The aspartokinase and homoserine dehydrogenase activities were eluted at different concentrations of $\mathrm{KCl}$ from DEAE-cellulose column. The aspartokinase was not inactivated after $30 \mathrm{~min}$ at $70^{\circ} \mathrm{C}$, but $30 \%$ of the original activity was lost after $30 \mathrm{~min}$ at $80^{\circ} \mathrm{C}$ and rapid inactivation occurred above $85^{\circ} \mathrm{C}$. The allosteric sensitivity of the enzyme was maintained even at $60 \sim 80^{\circ} \mathrm{C}$ but was reduced with the increase of temperature, accompanying desensitization above $80^{\circ} \mathrm{C}$. The heat stability of the enzyme activity and of the allosteric sensitivity was discussed in comparison with other allosteric enzymes of thermophiles.
\end{abstract}

Aspartokinase (ATP: L-aspartate 4-phosphotransferase, EC 2.7.2.4) is an allosteric enzyme which catalyzes the first reaction in the branched pathway for the biosynthesis of the amino acids of the aspartate family, starting with $\mathrm{L}$-aspartate and leading to L-lysine, L-threonine, and L-methionine. Various control patterns are known with the biosynthesis of aspartate family amino acids. For example, Escherichia coli $(\mathrm{K}-12)$ has three distinct aspartokinases, one of which is inhibited and repressed by L-lysine, a second is inhibited by L-threonine and repressed by L-threonine plus L-isoleucine, and a third one is repressed but not inhibited by L-methionine. In addition, in Escherichia coli, aspartokinase and homoserine dehydrogenase activities are associated in a complex protein. ${ }^{1)}$ On the other hand, in several species of Pseudomonas, ${ }^{2)}$ Bacillus $^{3,4)}$ and Brevibacterium ${ }^{5}$ a single aspartokinase is known to be under concerted feedback regulation by L-lysine and L-threonine.

One of the important properties of allosteric enzymes is that many of them lose their allosteric sensitivity by heat treatment above $50^{\circ} \mathrm{C}$.

* Present address: Kirin Brewery Co., Ltd., Yokohama, Kanagawa-ken.
Thus it is an interesting problem whether allosteric enzymes of thermophilic organisms can maintain their allosteric sensitivity even at the optimum temperature range for their growth (above $50^{\circ} \mathrm{C}$ ). Kuramitsu described that the aspartokinase from a moderate thermophile Bacillus stearothermophilus is feedback inhibited by both L-lysine and L-threonine in a concerted manner above $50^{\circ} \mathrm{C}$, but that the feedback sensitivity decreases as the assay temperature is increased and is almost completely lost above $60^{\circ} \mathrm{C}$, while the optimum temperature for the growth of the organism is about $60 \sim 65^{\circ} \mathrm{C}^{\circ}{ }^{\prime} \quad$ We described in 1970 that the aspartokinase of an extreme thermophile Thermus flavus AT-62 (the optimum temperature for growth is about $70^{\circ} \mathrm{C}$ ) exhibited allosteric sensitibity even at above $60^{\circ} \mathrm{C} .^{7}$ )

This paper describes the partial purification of the aspartokinase of an extreme thermophile Thermus flavus AT-62 and its allosteric nature at elevated temperatures.

\section{MATERIALS AND METHODS}

Growth of bacteria. Thermus flavus AT-62 was aerobically grown as described previously. ${ }^{8)}$ Cells 
were harvested near the end of the logarithmic growth phase and were kept in a deepfreeze at $-20^{\circ} \mathrm{C}$.

Enzyme assays. Aspartokinase activity was measured at $60^{\circ} \mathrm{C}$ by aspartylhydroxamate formation as described by Stadtman et al. ${ }^{9)}$ The amount of reaction product was calculated by comparison with $\mathrm{DL}$ aspartylhydroxamate as standard. Homoserine dehydrogenase activity was measured at $60^{\circ} \mathrm{C}$ as described previously. ${ }^{8}$ ) One milliunit of aspartokinase and homoserine dehydrogenase is defined as the amount of enzyme forming $1.0 \mathrm{nmol}$ of reaction product per min under the standard assay conditions.

Chemicals. L-Homoserine was a product of Kyowa Hakko Kogyo Co., Ltd., and all other amino acids used were purchased from Nippon Rikagakuyakuhin Co., Ltd. NADP and DL-aspartylhydroxamate were obtained from Oriental Yeast Co., Ltd, and from Sigma Chemical Co., respectively.

\section{Enzyme preparation}

Cell extract. The frozen cells ( $40 \mathrm{~g}$ ) were thawed and suspended in $50 \mathrm{ml}$ of $10 \mathrm{~mm}$ potassium phosphate buffer, $\mathrm{pH} 7.0$, and were sonicated for $7 \mathrm{~min}$ at $10 \mathrm{kc}$ using a Hitachi ultrasonic generator KMS-250 (Kubota Seisakusho, Ltd., Tokyo). The supernatant solution was retained and filled up to $100 \mathrm{ml}$ with the same phosphate buffer (Fraction I, Table I).

DEAE-cellulose column chromatography. Fraction I was adsorbed onto a column, $3.8 \times 24 \mathrm{~cm}$ of DEAEcellulose, previously equilibrated with $10 \mathrm{mM}$ potassium phosphate buffer, $\mathrm{pH}$ 7.0. After the column was washed with the phosphate buffer, elution was carried out with a linear gradient of $0 \sim 1.0 \mathrm{M} \mathrm{KCl}$ in 2.0 liters of the buffer; $20 \mathrm{ml}$ of fractions were collected. The elution pattern is shown in Fig. 1. The fractions containing aspartokinase activity were pooled and were dialysed against 3 liters of the phosphate buffer overnight (Fraction II).

2nd DEAE-cellulose column. Fraction II (72 ml) was adsorbed onto a DEAE-cellulose column $(3.1 \times$ $31 \mathrm{~cm}$ ), previously equilibrated with the phosphate buffer. After the column was washed with the phosphate buffer, a linear 1.0 liter gradient from 0 to $0.8 \mathrm{M}$ $\mathrm{KCl}$ in the phosphate buffer was applied. Fractions

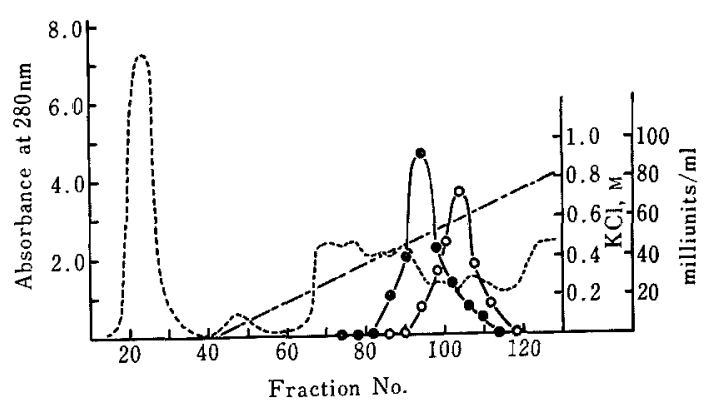

Frg. 1. Elution Pattern of Aspartokinase and Homoserine Dehydrogenase on a DEAE-cellulose Column.

A 100-ml of crude extract (Fraction I) was applied to a DEAE-cellulose column $(3.8 \times 24 \mathrm{~cm})$, previously equilibrated with $10 \mathrm{~mm}$ potassium phosphate buffer, $\mathrm{pH}$ 7.0. After the column was washed with the phosphate buffer, elution was carried out with a linear gradient of $0 \sim 1.0 \mathrm{KCl}$ in 2.0 liters of the buffer; $20 \mathrm{ml}$ of fractions were collected. -----, absorbance at 280 $\mathrm{nm},-1$, aspartokinase activity; $\mathrm{O}-\mathrm{O}$, homoserine dehydrogenase activity; -- - concentration of $\mathrm{KCl}$.

with high aspartokinase activity were pooled and concentrated by Diaflo ultrafiltration. The enzyme solution was dialyzed against 3 liters of $10 \mathrm{~mm}$ phosphate buffer, $\mathrm{pH} 7.0$, overnight and then against $500 \mathrm{ml}$ of $100 \mathrm{~mm}$ phosphate buffer, $\mathrm{pH} 7.0$, overnight. The preparation (Fraction III) was stored at $-20^{\circ} \mathrm{C}$.

As a summary of the purification is given in Table $I$, aspartokinase activity was purified about 11 -fold. It is demonstrated in Fig. 1 that aspartokinase and homoserine dehydrogenase activities could be separated each other in DEAE-cellulose column.

\section{RESULTS}

\section{Effect of aspartate family amino acids}

Among the amino acids of aspartate family only L-threonine exhibited inhibition of the aspartokinase and no concerted effect was observed (Table II). It is shown in Fig. 2 that the maximum inhibition by L-threonine is about $85 \%$ at $1.0 \mathrm{~mm}$ concentration.

TABle I. PURIfication of Thermus flavus Aspartokinase

\begin{tabular}{|c|c|c|c|c|c|}
\hline Step & $\mathrm{ml}$ & $\begin{array}{c}\text { Total } \\
\text { protein } \\
E_{280}\end{array}$ & $\begin{array}{c}\text { Total } \\
\text { activity } \\
\text { milliunits }\end{array}$ & $\begin{array}{l}\text { Specific } \\
\text { activity } \\
\text { milliunits } \\
\text { per } E_{280}\end{array}$ & $\begin{array}{c}\text { Recovery } \\
\%\end{array}$ \\
\hline I. Sonic extract & 100 & 5300 & 28000 & 5.3 & 100 \\
\hline II. DEAE-cellulose & 72 & 520 & 12700 & 24.4 & 45 \\
\hline III. 2nd DEAE-cellulose & 40 & 164 & 9610 & 58.6 & 34 \\
\hline
\end{tabular}




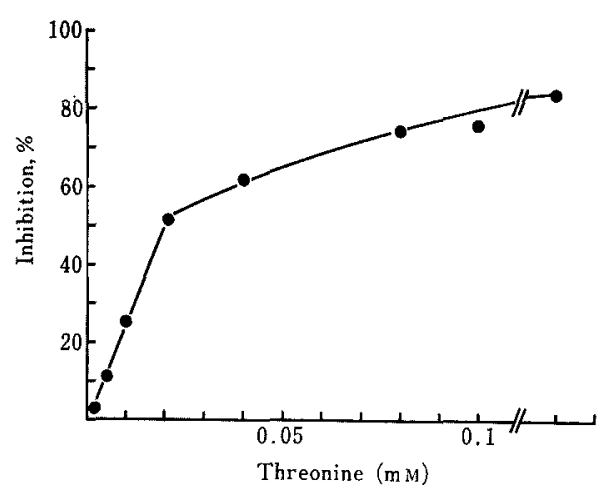

Fig. 2. Effect of L-Threonine Concentration on the Aspartokinase Activity.

Assays were performed at $60^{\circ} \mathrm{C}$ in the standard assay system added with L-threonine as variable.

\section{Table II. Efrect of Aspartate Family AMINo ACIDS ON THE ASPARTOKINASE OF Thermus flavus AT-62}

Aspartokinase activity was measured at $60^{\circ} \mathrm{C}$ with additives indicated in Table. Each reaction mixture contained $0.2 \mathrm{ml}$ of the partially purified enzyme preparation.

\begin{tabular}{|c|c|c|}
\hline Amino acid & $\begin{array}{c}\text { Concentration } \\
\mathrm{mM}\end{array}$ & $\begin{array}{c}\text { Increase } \\
\text { at } 540 \mathrm{~nm} \\
\left(60^{\circ} \mathrm{C}\right. \\
60 \mathrm{~min})\end{array}$ \\
\hline None & & 0.180 \\
\hline \multirow{3}{*}{ Threonine } & 0.1 & 0.035 \\
\hline & 1.0 & 0.035 \\
\hline & 10 & 0.025 \\
\hline \multirow[t]{3}{*}{ Lysine } & 0.1 & 0.180 \\
\hline & 1.0 & 0.180 \\
\hline & 10 & 0.175 \\
\hline \multirow[t]{3}{*}{ Methionine } & 0.1 & 0.190 \\
\hline & 1.0 & 0.190 \\
\hline & 10 & 0.185 \\
\hline \multirow[t]{3}{*}{ Isoleucine } & 0.1 & 0.200 \\
\hline & 1.0 & 0.200 \\
\hline & 10 & 0.190 \\
\hline \multirow[t]{3}{*}{ Homoserine } & 0.1 & 0.210 \\
\hline & 1.0 & 0.190 \\
\hline & 10 & 0.135 \\
\hline \multirow[t]{3}{*}{ Threonine + Lysine } & 0.1 (each) & 0.035 \\
\hline & 1.0 & 0.040 \\
\hline & 10 & 0.020 \\
\hline \multirow[t]{3}{*}{ Threonine + Methionine } & 0.1 (each) & 0.040 \\
\hline & 1.0 & 0.030 \\
\hline & 10 & 0.025 \\
\hline \multirow[t]{3}{*}{ Threonine + Isoleucine } & 0.1 & 0.065 \\
\hline & 1.0 & 0.035 \\
\hline & 10 & 0.040 \\
\hline
\end{tabular}

\section{Effect of temperature}

The optimum temperature of the enzyme activity, when measured with reaction time of $30 \mathrm{~min}$, was observed to be $75^{\circ} \mathrm{C}$ (Fig. 3). As shown in Fig. 4 the aspartokinase was very heat stable, not losing the activity after $30 \mathrm{~min}$ at or below $70^{\circ} \mathrm{C}$, but was rapidly inactivated above $80^{\circ} \mathrm{C}$ which is the upper limit temperature for the growth of the organism.

The feedback sensitivity of the aspartokinase

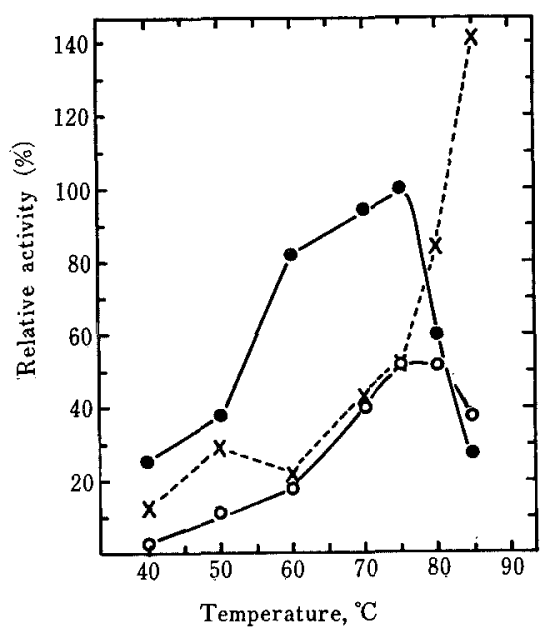

Fig. 3. Effect of Temperature on the Aspartokinase Activity and on the Feedback Inhibition.

Aspartokinase activity was measured in the presence $(\mathrm{O}-\mathrm{O})$ or absence $(-)$ of $0.1 \mathrm{mM} \mathrm{L}$-threonine at various temperatures. $\times---\times$ indicates the ratio of both activities.

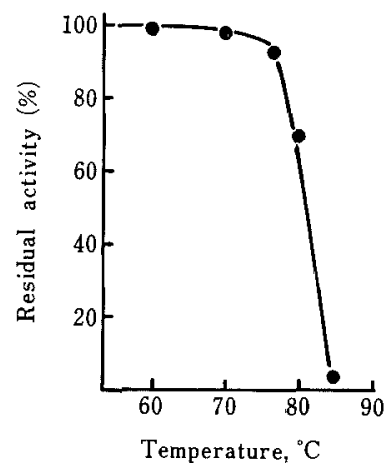

FIG. 4. Heat Stability of Aspartokinase.

After heat treatment at various temperatures in $50 \mathrm{~mm}$ potassium phosphate buffer, $\mathrm{pH} 7.0$ (adjusted at $60^{\circ} \mathrm{C}$ ), for $30 \mathrm{~min}$, the residual activity of the aspartokinase was measured at $60^{\circ} \mathrm{C}$. 
to L-threonine, even at $60^{\circ} \mathrm{C}$, is as high as that observed in Escherichia coli $\mathrm{K}-12$ at $30^{\circ} \mathrm{C}$, ${ }^{1}$ namely the concentration of L-threonine giving the half of maximum inhibition is about $0.02 \mathrm{~mm}$ (Fig. 2). However, the feedback sensitivity of the enzyme decreased with the rise of temperature; about $80 \%$ inhibition at $0.1 \mathrm{mM} \mathrm{L}$-threonine at $60^{\circ} \mathrm{C}$ decreased to $60 \%$ at $70^{\circ} \mathrm{C}$ and to $50 \%$ at $75^{\circ} \mathrm{C}$, and finally desensitization occurred above $80^{\circ} \mathrm{C}$. Heat inactivation as well as desensitization is considered to occur above $80^{\circ} \mathrm{C}$ and L-threonine seems to have protecting effect against heat inactivation of the enzyme.

\section{$p H$ stability and optimal $p H$}

The aspartokinase was stable at slight alkali to acidic $\mathrm{pH}$ range and was most stable at about $\mathrm{pH}$ 7. The enzyme was unstable at high alkali $\mathrm{pH}$ range, losing $90 \%$ of its original activity after $30 \mathrm{~min}$ at $70^{\circ} \mathrm{C}$ at $\mathrm{pH}$ 10.0 (Fig. 5). The optimum $\mathrm{pH}$ range for

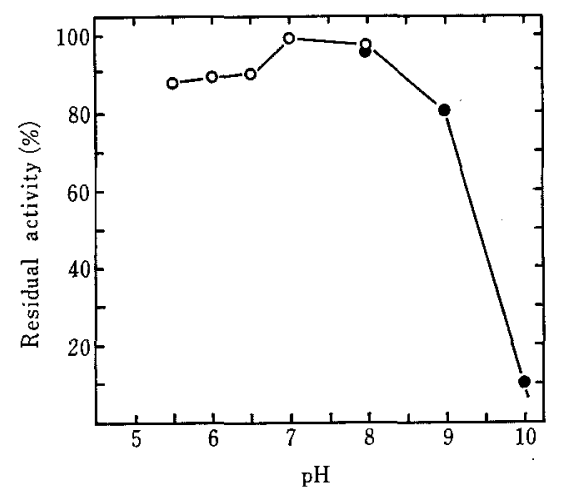

FIG. 5. Effect of pH on the Stability of the Aspartokinase.

The enzyme was incubated at $70^{\circ} \mathrm{C}$ for $30 \mathrm{~min}$ in buffers of various pHs adjusted at $70^{\circ} \mathrm{C}$, and then residual activities were measured with the standard assay produre.

$\mathrm{O}-\mathrm{O}, 0.1 \mathrm{M}$ potassium phosphate buffer; $0.1 \mathrm{M}$ borate buffer.

allosteric sensitivity to L-threonine was $\mathrm{pH} 6.5$ to 8 and significant desensitization occurred below pH 6 (Fig. 6).

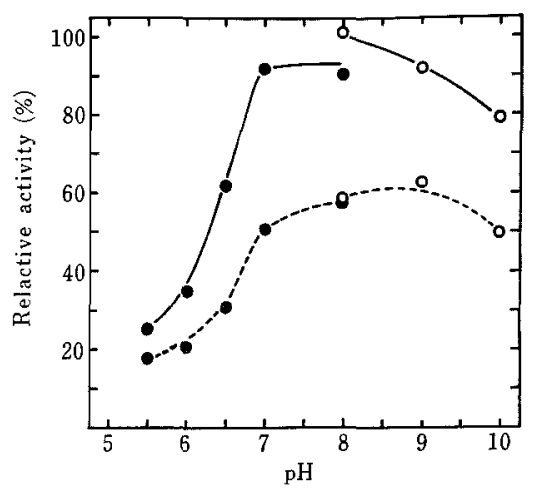

FIG. 6. Effect of $\mathrm{pH}$ on Activity and Feedback Sensitivity of the Aspartokinase.

The aspartokinase activity was measured with the standard assay procedure except that the $\mathrm{NH}_{2} \mathrm{OH}$. $\mathrm{HCl}$ was adjusted to the $\mathrm{pH}$ of each buffered mixture at $60^{\circ} \mathrm{C}$, enzyme activity in $0.1 \mathrm{M}$ phosphate buffer; --- enzyme activity in $0.1 \mathrm{M}$ phosphate buffer in the presence of $0.02 \mathrm{~mm}$ L-threonine; $\mathrm{O}-\mathrm{O}$, enzyme activity in $0.1 \mathrm{M}$ borate buffer; $\bigcirc---\bigcirc$, enzyme activity in $0.1 \mathrm{M}$ borate buffer in the presence of 0.02 mM L-threonine.

\section{DISCUSSION}

The aspartokinase was purified about 11folds from Thermus flavus AT-62 cells. It was difficult to purify the enzyme to homogeneity because of both the low intracellular enzyme level and the presence of viscous lipoid components. The attempt to purify the enzyme using affinity adsorbent such as N- $\omega$-aminohexyl-L-aspartic acid $^{10)}$ (kindly provided by Dr. I. Chibata, Tanabe Seiyaku Co., Ltd., Osaka), e-aminocaproyl-L-aspartic acid and $\varepsilon$-aminocaproyl-L-threonine, each of which was coupled to Sepharose 4-B, did not produce satisfactory results. From the results of purification it seems, unlike the case of Escherichia coli, ${ }^{1)}$ that the organism has a single aspartokinase regulated by L-threonine alone, without forming complex with homoserine dehydrogenase.

In the previous paper ${ }^{7)}$ we reported that the aspartokinase is regulated by L-threonine plus L-lysine in concerted manner in the experiments using crude cell extract preparation. The presence of high concentration of viscous lipoid substance in crude preparation might 
interfere the development of color of the reaction product, leading to wrong conclusion.

It is clear that the aspartokinase of an extreme thermophile Thermus flavus AT-62 is far more heat stable compared with that of Bacillus stearothermophilus ${ }^{(6)}$ in the respects of heat stability of the enzyme activity as well as of allosteric sensitivity. In spite of such an strong heat stability allosteric sensitivity of the enzyme decreased with the rise of temperature above $60^{\circ} \mathrm{C}$ and desensitization occurred above $80^{\circ} \mathrm{C}$ (the optimum temperature for growth of the organism is about $70^{\circ} \mathrm{C}$ ). We described elsewhere about the same behavior to temperature of isocitrate dehydrogenase of Thermus flavus AT-62.11,12) As already described in introduction the feedback sensitivity of the aspartokinase of moderate thermophile Bacillus stearothermophilus is almost completely lost above $60^{\circ} \mathrm{C}$, while the optimum temperature for the growth of the organism is $60 \sim 65^{\circ} \mathrm{C}$.

These facts may imply that certain enzymes of thermophiles are not ones adapted well to high temperature circumstances in respects to regulatory functions or to affinity for substrates or cofactors, in spite of the remarkable heat stability of enzymatic activity. Alternative possibility is that there might be some stabilizing or protecting factors in vivo. In addition far higher protein concentration in vivo than that in experimental conditions may contribute to the heat stability of most intracellular enzyme proteins.

It is interesting that the L-threonine deaminase of Bacillus stearothermophilus has an higher heat stability than that of the aspartokinase of the same organism in respect to allosteric sensitivity. ${ }^{13)}$ The fructose-bis-phosphatase of Thermus thermophilus (the optimum and maximum temperatures for growth are $70 \sim 75$ and $85^{\circ} \mathrm{C}$, respectively) has also higher heat stability in their enzymatic activities and in regulatory functions, ${ }^{14)}$ although their allosteric sensitivity also decreases above $75^{\circ} \mathrm{C}$ with the increase of temperature.

It seems that there are many types of thermophilic or thermostable enzymes of thermophiles in respect to their enzymatic activity $\left(V_{\max }\right)$ or to affinity (or sensitivity) for ligands ( $K m$ or $K i)$ including allosteric sensitivity. Relationship between temperature dependent kinetic properties of purified thermophilic enzymes and physiological concentrations of substrates and effectors in vivo at elevated temperatures remains to be resolved.

Acknowledgment. The authors wish to express their thanks to the Central Research Laboratories of Ajinomoto Co, Ltd. (Kawasaki, Kanagawa-ken) for large-scale cultivation of the organism.

\section{REFERENCES}

1) J.- C. Patte, P. Truffa-Bachi and G. N. Cohen, Biochim. Biophys. Acta, 128, 426 (1966).

2) R.- G. Malka, M. Poiret and G. N. Cohen, ibid., 206, 17 (1970).

3) M. L. Hampton, N. G. McCormick, N. C. Behforouz and E. Freese, J. Bacteriol., 108, 1129 (1971).

4) B. H. Gray and R. W. Bernlohr, Biochim. Biophys. Acta, 178, 248 (1069).

5) R. Miyajima, S. Otsuka and I. Shiio, J. Biochem., 63, 139 (1968).

6) H. K. Kuramitsu, J. Biol. Chem., 245, 2991 (1970).

7) T. Saiki and K. Arima, Agric. Biol. Chem., 34, 1762 (1970).

8) T. Saiki, H. Shinshi and K. Arima, J. Biochem., 74, 1239 (1973).

9) E. R. Stadtman, G. N. Cohen, G. LeBras, and H. de Robichon-Szulmajster, J. Biol. Chem., 236 2033 (1961).

10) T. Tosa, T. Sato, R. Sano, K. Yamamoto, Y. Matuo and I. Chibata, Biochim. Biophys. Acta, 334, 1 (1974).

11) T. Saiki and K. Arima, J. Biochem., 77, 233 (1975).

12) T. Saiki, I. Mahmud, N. Matsubara, K. Taya and $\mathrm{K}$. Arima, "Proceedings of the International Symposium on Enzymes and Proteins from Thermophilic Microorganisms," ed. by H. Zuber, Birkhauser Verlag, Basel, 1976, pp. 169 183.

13) P. A. Thomas and H. K. Kuramitsu, Arch. Biochem. Biophys., 145, 96 (1971).

14) M. Yoshida, T. Oshima and K. Imahori, J. Biochem., 74, 1183 (1973). 